\title{
A long, long haul against a severe disease
}

\author{
Jong-Yeon Park \\ Department of Anesthesiology and Pain Medicine, Asan Medical Center, University of Ulsan College of Medicine, Seoul, Korea
}

\begin{abstract}
Although achievements in modern medicine have enabled mankind to cure or control many diseases, numerous challenges remain. Acute kidney injury (AKI), a serious illness causing significant mortality and morbidity, is one such challenge [1]. AKI occurs in the perioperative period and is diagnosed by laboratory abnormalities, such as elevated blood urea nitrogen and creatinine, or by a drop in urine output. AKI may lead to a number of complications, including metabolic acidosis, high potassium levels, uremia, changes in body fluid balance, and effects on other organ systems. The current treatment for AKI consists of supportive care such as renal replacement therapy as well as treatment of the underlying disorder.

Over the past few years, international guideline groups have attempted to establish consistent definitions and staging systems for AKI. The staging system known as Risk, Injury, Failure, Loss, End (RIFLE) was established in 2004 [2]. This was modified to create the Acute Kidney Injury Network (AKIN) [3], and then further modified to create the Kidney Disease: Improving Global Outcomes (KDIGO) system in 2012 [4]. These systems are based on serial creatinine measurements. National Institute for Health and Care Excellence (NICE) guidelines published in 2013 suggest that these systems need further development and simplification to be useful for clinicians.

Recent studies have found several biomarkers for AKI that reflect glomerular filtration rate decrease and renal tubular
\end{abstract}

injury early after cardiac surgery, including urinary neutrophil gelatinase associated lipocalin (NGAL) [5], liver-type fatty acidbinding protein (L-FABP) [6], kidney injury molecule-1 (KIM-1) [7], interleukin-18 (IL-18) [8], and serum cystatin C [9]. However, controversies regarding the accuracies of these biomarkers in the clinical setting still exist.

No therapeutic modalities to date have shown efficacy for treating AKI. In severe cases, hemodialysis can be used. However, hemodialysis is difficult and time-consuming, and can cause complications including low blood pressure, fatigue, chest pains, leg-cramps, nausea, headache, and sepsis. Patients undergoing hemodialysis have trouble remaining employed, and face severe economic difficulties. Although kidney transplantation is an effective treatment method, patients are rarely able to find a suitable kidney donor. Even after a kidney transplant, patients may suffer from transplant rejection, infection, sepsis and side effects of medications. Therefore, prevention of AKI is more important than treatment. Anesthesiologists must strive to avoid hypotension and drugs with renal toxicity during surgical procedures.

Recently, it was reported that human liver tissue was built using a three-dimensional printer. Perhaps in 20 or 30 years, it will be possible to replace non-functional human organs with artificially created organs at relatively low cost. However, until that day arrives, medical doctors, including anesthesiologists, must strive to cure or control AKI and other severe diseases.

Corresponding author: Jong-Yeon Park, M.D., Ph.D., Department of Anesthesiology and Pain Medicine, Asan Medical Center, University of Ulsan College of Medicine, 88 Olympic-ro 43-gil, Songpa-gu, Seoul 138-736, Korea. Tel: 82-2-3010-3867, Fax: 82-2-470-1363, E-mail: jongyeon_ park@amc.seoul.kr

(c) This is an open-access article distributed under the terms of the Creative Commons Attribution Non-Commercial License (http:// creativecommons.org/licenses/by-nc/3.0/), which permits unrestricted non-commercial use, distribution, and reproduction in any medium, provided the original work is properly cited. 


\section{References}

1. Jung HS, Joo JD, Kim DW, In JH, Roh M, Jeong JT, et al. Effect of milrinone on the inflammatory response and NF-kB activation in renal ischemia-reperfusion injury in mice. Korean J Anesthesiol 2014; 66: 136-42.

2. Bellomo R, Ronco C, Kellum JA, Mehta RL, Palevsky P. Acute renal failure - definition, outcome measures, animal models, fluid therapy and information technology needs: the Second International Consensus Conference of the Acute Dialysis Quality Initiative (ADQI) Group. Crit Care 2004; 8: R204-12.

3. Mehta RL, Kellum JA, Shah SV, Molitoris BA, Ronco C, Warnock DG, et al. Acute Kidney Injury Network: report of an initiative to improve outcomes in acute kidney injury. Crit Care 2007; 11: R31.

4. Khwaja A. KDIGO Clinical Practice Guidelines for Acute Kidney Injury. Nephron Clin Pract 2012; 120: 179-84.

5. Mishra J, Dent C, Tarabishi R, Mitsnefes MM, Ma Q, Kelly C, et al. Neutrophil gelatinase-associated lipocalin (NGAL) as a biomarker for acute renal injury after cardiac surgery. Lancet 2005; 365: 1231-8.

6. Portilla D, Dent C, Sugaya T, Nagothu KK, Kundi I, Moore P, et al. Liver fatty acid-binding protein as a biomarker of acute kidney injury after cardiac surgery. Kidney Int 2008; 73: 465-72.

7. Han WK, Waikar SS, Johnson A, Betensky RA, Dent CL, Devarajan P, et al. Urinary biomarkers in the early diagnosis of acute kidney injury. Kidney Int 2008; 73: 863-9.

8. Parikh CR, Mishra J, Thiessen-Philbrook H, Dursun B, Ma Q, Kelly C, et al. Urinary IL-18 is an early predictive biomarker of acute kidney injury after cardiac surgery. Kidney Int 2006; 70: 199-203.

9. Herget-Rosenthal S, Marggraf G, Hüsing J, Göring F, Pietruck F, Janssen O, et al. Early detection of acute renal failure by serum cystatin C. Kidney Int 2004; 66: 1115-22. 